\title{
Modulation of Competence for Genetic Transformation in Streptococcus pneumoniae
}

\author{
By JAU-DER CHEN AND DONALD A. MORRISON* \\ Laboratory for Cell, Molecular, and Developmental Biology, University of Illinois at Chicago, \\ PO Box 4348, Chicago, Illinois 60680, USA
}

(Received 9 December 1986; revised 26 February 1987)

The spontaneous development of competence by cultures of Streptococcus pneumoniae in casein hydrolysate medium was strongly dependent on the initial $\mathrm{pH}$ of the culture medium. Cells growing in cultures beginning with a wide range of initial $\mathrm{pH}$ values (6.8 to 8.0) all developed competence, as measured by $\left[{ }^{3} \mathrm{H}\right] \mathrm{DNA}$ uptake, $\left[{ }^{3} \mathrm{H}\right] \mathrm{DNA}$ degradation and genetic transformation; but the initial $\mathrm{pH}$ of the medium affected both the timing of the occurrence of competence and the number of times the culture became competent. In cultures grown in media of lower initial $\mathrm{pH}$, competence occurred only once, at high population densities, while in more alkaline media a succession of competence cycles occurred, beginning at lower cell densities. The critical population density required for the initiation of competence varied tenfold over the $\mathrm{pH}$ range studied. Successive competence cycles in an alkaline medium were not equivalent: while the percentage of competent cells in the first competence cycle was high (approximately $80 \%$ ), that in the second competence cycle was lower (approximately $12 \%$ ). Correspondingly, competence-specific proteins were less prominent in the labelled-protein pattern of the second competence cycle than in that of the first. These features of the physiology of competence control make it possible to adjust the expression of competence to suit various experimental requirements.

\section{INTRODUCTION}

The control of the expression of competence for genetic transformation among naturally transformable bacteria is not well understood. Piliated cells are competent throughout culture growth in Neisseria gonorrhoeae (Sparling, 1966; Biswas et al., 1977); Bacillus subtilis develops competence slowly during the transition from exponential-phase growth to the stationary phase (Dooley et al., 1971; Nester, 1964; Bott \& Wilson, 1967); and Haemophilus influenzae is most competent in conditions where growth is blocked but protein synthesis continues (Leidy et al., 1962; Spencer \& Herriott, 1965; Herriott et al., 1970). In contrast, in Streptococcus species, competence is a transitory phenomenon occurring optimally during exponential-phase growth (Tomasz \& Hotchkiss, 1964; Tomasz, 1966, 1971 ; Pakula \& Walczak, 1963). Streptococci offer a particularly favourable system for analysis, because competence is separated from other major cell changes associated with entry into the stationary phase of growth, is inducible, and typically occurs in nearly all the cells of a culture at once.

Competence in Streptococcus pneumoniae is associated with the induction of a small set of new proteins (Morrison \& Baker, 1979; Morrison, 1981), temporary cessation of synthesis of most other proteins, and the appearance of a number of unusual cell properties, including an efficient system for taking up DNA and promoting genetic recombination between that DNA and the cell chromosome (Avery et al., 1944; Fox \& Allen, 1964; McCarty, 1980; Morrison et al., 1982).

Abbreviations: CF, competence factor; CTM, complete transformation medium; LM, low-methionine labelling medium; PMSF, phenylmethylsulphonyl fluoride. 
A similar protein shift occurs in Streptococcus sanguis (Raina \& Ravin, 1980). The drastic protein shift seen in competent cultures suggests that nearly all cells participate in the redirection of protein synthesis accompanying competence. Genetic and physical studies investigating the composition of a competent $S$. pneumoniae culture have independently demonstrated that nearly all cells were simultaneously competent in such a culture (Javor \& Tomasz, 1968; Porter \& Guild, 1969).

Competence in $S$. pneumoniae is under a very specific set of controls (Tomasz \& Hotchkiss, 1964; Tomasz, 1966, 1973). As a growing culture reaches a specific cell density, the cells become competent for transformation (Porter \& Guild, 1969; Javor \& Tomasz, 1968). This critical cell density is determined by a mechanism involving a secreted protein, competence factor (CF), acting as a feedback signal sensitive to the population level of the culture; when CF accumulates to a certain level, it induces cells in the culture to become competent (Tomasz \& Hotchkiss, 1964; Tomasz \& Mosser, 1966; Tomasz, 1966). Competence terminates after a short time and an inhibitor of activation is released (Tomasz, 1973). Competence can be artificially provoked at lower cell densities by adding exogenous $\mathrm{CF}$. Other details of conditions required or favourable for competence are less well defined.

In the course of developing screening procedures for isolating transformation-deficient mutants (Morrison et al., 1983), we found it important to control the critical cell density at which cultures of pneumococcal strains developed competence. When the final culture density was to be lowered by limiting the energy source (sugar), yet competence development was required, it was important to use culture conditions in which competence would occur at low cell densities; otherwise growth could stop before the critical density had been achieved. In contrast, induction of competence at high culture densities is important for providing large amounts of starting material for biochemical assays of events in competent cells.

Various laboratories have reported critical cell densities varying between $2 \times 10^{6} \mathrm{ml}^{-1}$ and $2 \times 10^{8} \mathrm{ml}^{-1}$ (Ottolenghi \& Hotchkiss, 1962; Tomasz \& Hotchkiss, 1964; Tomasz, 1966; Gurney \& Fox, 1968; Porter \& Guild, 1969; Morrison, 1977). Competence appears in cultures of pneumococci growing in appropriate media at a specific cell density. This critical density is reproducible from experiment to experiment but varies considerably with medium composition, bacterial strain and other unknown variables (Tomasz \& Hotchkiss, 1964; McCarty, 1980). However, control of this parameter has not been described. There have been, however, several indications that culture $\mathrm{pH}$ is an important variable. For example, for $S$. pneumoniae strain R6 competence occurs during growth in a complex medium with a $\mathrm{pH}$ of 7.6 , but not in the same medium adjusted to $\mathrm{pH} 6.7$ (Tomasz \& Mosser, 1966). The optimum pH for response to isolated CF was near $7 \cdot 7$, and CF activity decreased exponentially over three orders of magnitude between $\mathrm{pH} 7.7$ and 6.9 (Tomasz, 1966). Also, Tiraby et al. (1973) reported that transformation during surface colony growth in the presence of DNA required a high initial pH for optimum expression of competence.

\section{METHODS}

Bacterial strains. S. pneumoniae strain CP1015 (a str-1 derivative of strain Rx; Morrison et al., 1983) served as recipient in transformation experiments. $\left[{ }^{3} \mathrm{H}\right] \mathrm{DNA}$ was extracted from strain CP1016 (str-1 ery-2 nov-1 vlt) (Morrison et al., 1984) after labelling with [ $\left.{ }^{3} \mathrm{H}\right]$ thymidine, as described by Morrison (1977). In other cases unlabelled DNA from strain 5MC (Cato \& Guild, 1968) was used as donor.

Culture conditions. Complete transformation medium (CTM) was that described by Peterson \& Guild (1968), supplemented with choline to avoid choline-limitation at high culture densities. A mixture of $5 \mathrm{~g}$ tryptone (Difco), $10 \mathrm{~g}$ enzymic casein hydrolysate (ICN Nutritional Biochemicals), $1 \mathrm{~g}$ yeast extract (Difco), $5 \mathrm{mg}$ choline and $5 \mathrm{~g}$ $\mathrm{NaCl} \mathrm{l}^{-1}$ was sterilized for $50 \mathrm{~min}$ at $121^{\circ} \mathrm{C}$ and then brought to $0.2 \%$ glucose, $0.2 \% \mathrm{BSA}, 1 \mathrm{~mm}-\mathrm{CaCl}_{2}$ and $0.166 \mathrm{M}$-dipotassium phosphate before use. In addition, the initial $\mathrm{pH}$ was adjusted by adding $0-10 \mathrm{mM}$ of $\mathrm{HCl}$ or $\mathrm{NaOH} 1^{-1}$. pH was measured at $25^{\circ} \mathrm{C}$ with a model 26 Radiometer $\mathrm{pH}$ meter equipped with an Orion \#91-103 combination electrode, after standardization with Beckman buffers at $\mathrm{pH} 7$ and $\mathrm{pH} 10$. Culture density was measured as optical density at $550 \mathrm{~nm}$ in a Coleman $\mathrm{Jr}$ II colorimeter using $18 \mathrm{~mm}$ diameter culture tubes. Competence was assayed by determining $\left[{ }^{3} \mathrm{H}\right] \mathrm{DNA}$ solubilization or uptake, and DNAase-resistant transformants, as described previously (Morrison et al., 1983). Low-methionine labelling medium (LM) was prepared as described previously (Morrison, 1978). 
Protein labelling and analysis. This was done by procedures similar to those outlined previously (Morrison \& Baker, 1979; Morrison, 1981). Samples to be pulse-labelled were harvested by adding glycerol to $10 \%(\mathrm{v} / \mathrm{v})$, and freezing in a dry-ice-acetone bath. For labelling, the culture samples were thawed at $0{ }^{\circ} \mathrm{C}$, washed in $\mathrm{LM}$, and suspended in $\mathrm{LM}$ at $4 \times 10^{8}$ cells $\mathrm{ml}^{-1}$. A $400 \mu$ portion of this suspension, mixed with $10 \mu \mathrm{Ci}(370 \mathrm{kBq})$ $\left[{ }^{35} \mathrm{~S}\right]$ methionine, was incubated for $10 \mathrm{~min}$ at $37^{\circ} \mathrm{C}$. Incorporation was terminated by adding $200 \mu \mathrm{l}$ cold $\mathrm{CTM}$ $(+30 \%, v / v$, glycerol $)$, and the labelled cells were frozen at $-80^{\circ} \mathrm{C}$. To prepare an extract for analysis, the frozen labelled cells were thawed at $0^{\circ} \mathrm{C}$, washed in $0.01 \mathrm{M}$-Tris, $1 \mathrm{mM}$-EDTA pH 8.0 in the cold, and suspended in $300 \mu \mathrm{l}$ lysis buffer, containing 0.01 M-Tris pH 8.0, $1 \mathrm{mM}-\mathrm{EDTA}, 1 \mathrm{mM}-\mathrm{PMSF}, 0.4 \%$ Triton X-100, $4 \mathrm{mM}-\mathrm{NaCl}, 10 \mu \mathrm{g}$ DNAase $I \mathrm{ml}^{-1}, 50 \mu \mathrm{g} \mathrm{RNAase} \mathrm{ml}^{-1}$, and $5 \mathrm{~mm}-\mathrm{MgCl}_{2}$. After incubation at $37^{\circ} \mathrm{C}$ for $5 \mathrm{~min}$, Sarkosyl was added to $0.05 \%$ and EDTA to $5 \mathrm{mM}$, and incubation continued for $3 \mathrm{~min}$. The chilled lysate was mixed with $150 \mu 11 \%$ tRNA and $150 \mu \mathrm{l} 40 \%(\mathrm{w} / \mathrm{v})$ TCA. The TCA precipitates, after storage for up to $12 \mathrm{~h}$ at $0{ }^{\circ} \mathrm{C}$, were washed twice with $1 \mathrm{ml}$ acetone, dried in vacuo, and redissolved in $25 \mu \mathrm{l} 100 \mathrm{mM}$-Tris $/ \mathrm{HCl} \mathrm{pH} 8 \cdot 0,2 \%$ (w/v) SDS, $1 \%$ mercaptoethanol. After mixing with $25 \mu$ l sucrose-dye solution to bring the whole to $20 \mathrm{mM}-\mathrm{EDTA}, 0.01 \%$ bromphenol blue, $10 \%(\mathrm{w} / \mathrm{v})$ sucrose, $50 \mathrm{mM}$-Tris $/ \mathrm{HCl} \mathrm{pH} \mathrm{8.0,} \mathrm{the} \mathrm{extract} \mathrm{was} \mathrm{heated} \mathrm{in} \mathrm{a} \mathrm{boiling} \mathrm{water} \mathrm{bath} \mathrm{for}$ $5 \mathrm{~min}$, and either stored at $-20^{\circ} \mathrm{C}$ or analysed immediately. After TCA-insoluble ${ }^{35} \mathrm{~S}$ had been determined for each sample, processing losses were accounted for by loading 10000 c.p.m. in each well of a $12-25 \%$ (w/v) PAGE gel. The gel was prepared, run and analysed as described by Laemmli (1970). Fluorography was done as described by Laskey \& Mills (1975).

Congression analysis. Competent cultures were prepared under conditions like those described in Fig. 2, panel 8 (double cycle), and panel 3 (single late cycle). Samples were exposed to DNA for $10 \mathrm{~min}$ at 10 min intervals, diluted 10-fold in DNAase-CTM, incubated at $37^{\circ} \mathrm{C}$ for $120 \mathrm{~min}$ to complete segregation, diluted, and plated on drug agar plates. For selection of drug-resistant transformants, the top layer of agar contained erythromycin at $0.5 \mu \mathrm{g} \mathrm{ml}^{-1}$ and/or novobiocin at $10 \mu \mathrm{g} \mathrm{ml}^{-1}$. Competence peaks were identified by immediate analysis of the TCA-soluble products of DNA transport and degradation measured in a duplicate set of samples exposed to $\left[{ }^{3} \mathrm{H}\right] \mathrm{DNA}$ for the same $10 \mathrm{~min}$ intervals. The genetic analysis was done for samples identified as representing the first half of each competence cycle.

\section{RESULTS AND DISCUSSION}

\section{Critical cell density for competence determined by initial $\mathrm{pH}$}

To examine the influence of $\mathrm{pH}$ on development of competence, we followed both parameters in detail during growth of strain CP1015 in CTM adjusted to various initial $\mathrm{pH}$ values between 7.2 and 8.2 (Figs 1 and 2). During exponential growth, the $\mathrm{pH}$ decreased continuously and

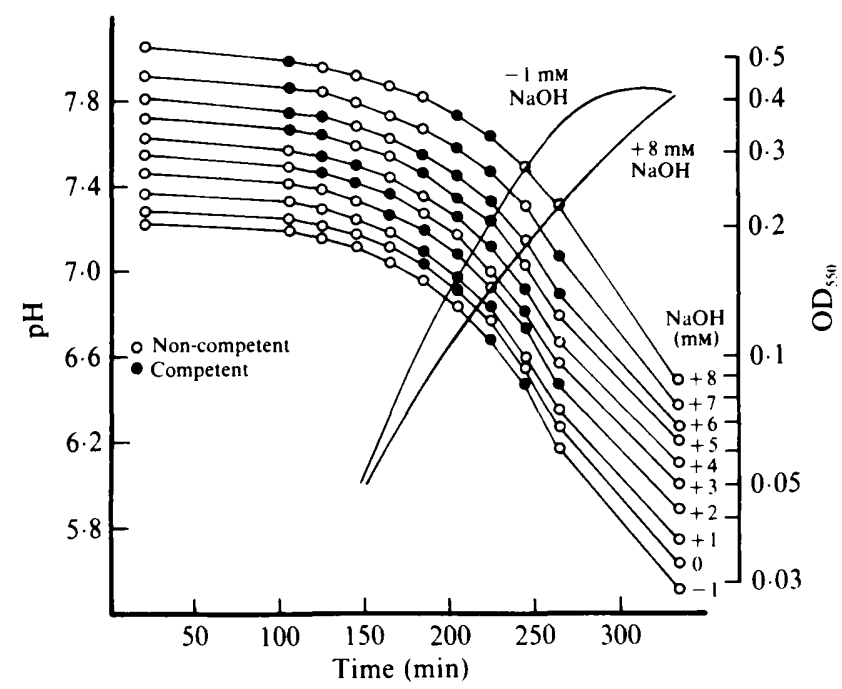

Fig. 1. Effect of the initial $\mathrm{pH}$ of the culture medium on culture acidification and on development of competence. Ten parallel cultures, identical except for addition of the indicated amounts of $\mathrm{NaOH}$ (or $\mathrm{HCl}, \cdot-1$ '), were prepared in CTM and inoculated with $0.01 \mathrm{vol}$. of a culture frozen at $\mathrm{OD}_{550} 0.2$. During incubation at $37^{\circ} \mathrm{C}, \mathrm{OD}_{550}$, competence (as DNA digestion activity and $\mathrm{pH}$ (circles) were measured at $20 \mathrm{~min}$ intervals. Growth $\left(\mathrm{OD}_{550} ;-\right)$ ) is shown for the two extreme cultures (treated with $1 \mathrm{mM}-\mathrm{HCl}$ and with $8 \mathrm{mM}-\mathrm{NaOH}$, respectively). Samples in which competence exceeded $15 \%$ of the maximum level. 


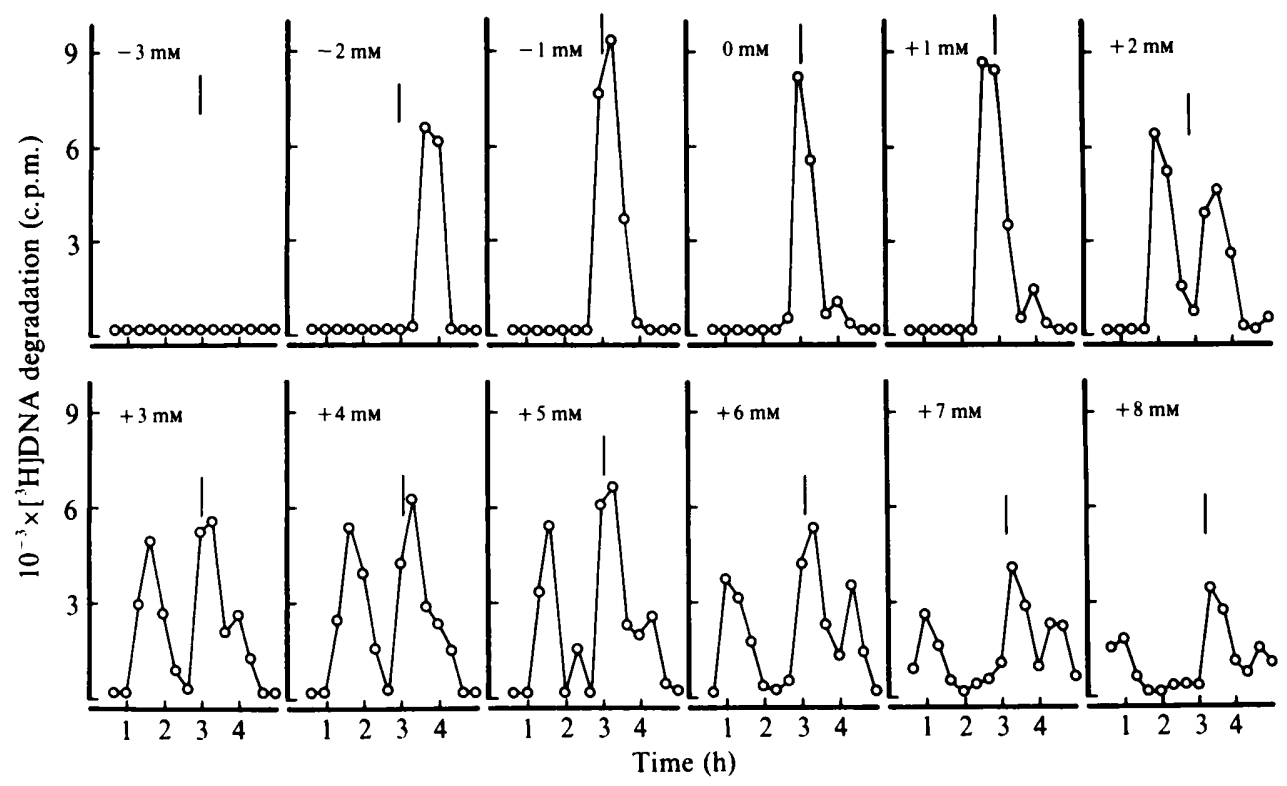

Fig. 2. Kinetics of competence development in cultures initiated at $\mathrm{pH}$ values between 6.79 and 8.25. Twelve cultures were inoculated as in Fig. 1 after adjustment of the $\mathrm{pH}$ by addition of the indicated amounts of $\mathrm{HCl}$ or $\mathrm{NaOH}$, producing initial $\mathrm{pH}$ values of $6.79,6.95,7 \cdot 04,7 \cdot 16,7 \cdot 24,7.29,7.37,7 \cdot 45$, $7.61,7 \cdot 70,7.93$ and 8.25 , respectively. Competence was measured as acid-soluble label produced from $\left[{ }^{3} \mathrm{H}\right] \mathrm{DNA}(45000$ c.p.m. per $0.5 \mathrm{ml}$ sample) incubated with culture samples for $20 \mathrm{~min}$. The vertical line in each panel indicates the time at which that culture reached $\mathrm{OD}_{5 s_{0}} 0 \cdot 1$.

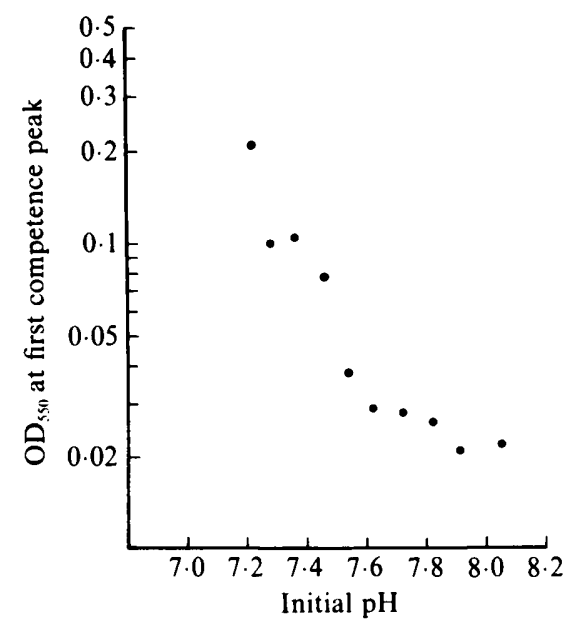

Fig. 3. Relation between initial culture $\mathrm{pH}$ and the population density $\left(\mathrm{OD}_{550}\right)$ at the first peak of competence. The data shown are for the cultures described in Fig. 1.

reproducibly as acid products of metabolism titrated the culture medium. The cell density at which competence first appeared varied in a continuous fashion with the initial $\mathrm{pH}$ of the growth medium: competence first appeared at lower densities for higher initial $\mathrm{pH}$ values. [A similar phenomenon may also be noted in the competence experiments reported by Grist \& Butler (1981), for some other combinations of pneumococcal strains and media.] The pattern 
seen in Figs 1 and 2 is not consistent with a single 'optimum $\mathrm{pH}$ ' for competence; competence induction actually occurred over a wide pH range (6.7 to 7.9 ). Rather, the critical cell density required to elicit competence was lower in more alkaline media. This appears to be consistent with earlier data (Tomasz \& Mosser, 1966) showing that the activity of isolated CF increases continuously from $\mathrm{pH} 6.9$ to $7 \cdot 7$.

By extrapolation of the summary data in Fig. 3, it appears that, while competence can occur at a stage in culture growth with pH less than 6.7 (see Fig. 1), it never appears in media with an initial $\mathrm{pH}$ below approximately 7.0 because the critical cell density is then set near or above the normal limit of culture growth; i.e. stationary phase is approached below the critical cell density.

It has not previously been reported that the cell density at which a culture develops competence varies continuously with the initial $\mathrm{pH}$ of the culture medium. Since small $\mathrm{pH}$ changes have strong effects on the competence cycle, this is an effect that can easily be overlooked. This phenomenon makes it possible to ensure competence early in culture growth when desired, but also allows the controlled delay of induction of competence until lateexponential phase for higher yields of competent cells.

This phenomenon also appears to account for the high optimum $\mathrm{pH}$ found for two kinds of competence experiments described elsewhere (Morrison et al., 1983): (a) colonies grown on limiting sucrose in agar medium containing donor DNA, and $(b)$ liquid cultures grown on limiting glucose to early-stationary phase, in otherwise complete competence medium. For cultures growing under sugar limitation, reliable competence depends on setting the critical cell density below the artificially reduced growth limit; it appears from these results that an appropriate choice of initial $\mathrm{pH}$ can achieve this effect.

We suggest that a simple hypothesis accounting for these results is that they represent the consequences for the model of Tomasz (1966) of the strong pH dependence of CF activity (Tomasz \& Mosser, 1966). Thus, CF may be produced constitutively by non-competent cells at a fixed rate per cell, independent of $\mathrm{pH}$ or population level, while the critical $\mathrm{CF}$ level for inducing competence (and thus the population level required to achieve this concentration) depends strongly on $\mathrm{pH}$.

\section{Successive competence cycles are not equivalent}

In cultures initiated at a $\mathrm{pH}$ which allowed competence to develop significantly earlier than the last two generations of growth, a second wave of competence appeared approximately 1-2 doubling times after the first (Figs 1 and 2). This second competence cycle is often seen when competence is measured throughout the period from early-exponential phase to stationary phase, and was described by Hotchkiss (1954) for the case of competence in thermally synchronized cultures. The nature of competence in this second cycle, however, has not been investigated in detail. Since $\mathrm{pH}$ regulation provided two different possible sources of highdensity competent cultures (the first peak in a low-pH culture, or the second peak in a more alkaline culture), we compared the nature of the competent cells found at the first and second competence cycles in a culture initiated at high $\mathrm{pH}$. The result shown in Fig. 4(a) was typical: cells from the second peak yielded fewer or only modestly more transformants than those from the first, despite a much higher total cell number. This suggested that competence in the second cycle was in some way less efficient than that in the first. Assay of the appearance of new proteins (Fig. $4 b, c$ ) confirmed this impression biochemically: the characteristic competencespecific eclipse complex protein $\left(M_{r} 19000\right.$; arrowed) was induced during the second cycle of competence, but at a clearly lower level than during the first.

To distinguish between a population of less competent cells and one in which normally competent cells comprised a minority, we used the congression method of Porter \& Guild (1969) to estimate genetically the fraction of competent cells. The fraction of competent cells in the first cycle of competence was very high, as expected, but was about seven-fold lower in the second (Table 1). Competence in the delayed cycle of the more acidic culture was just as high as that for the first cycle of the alkaline culture. 


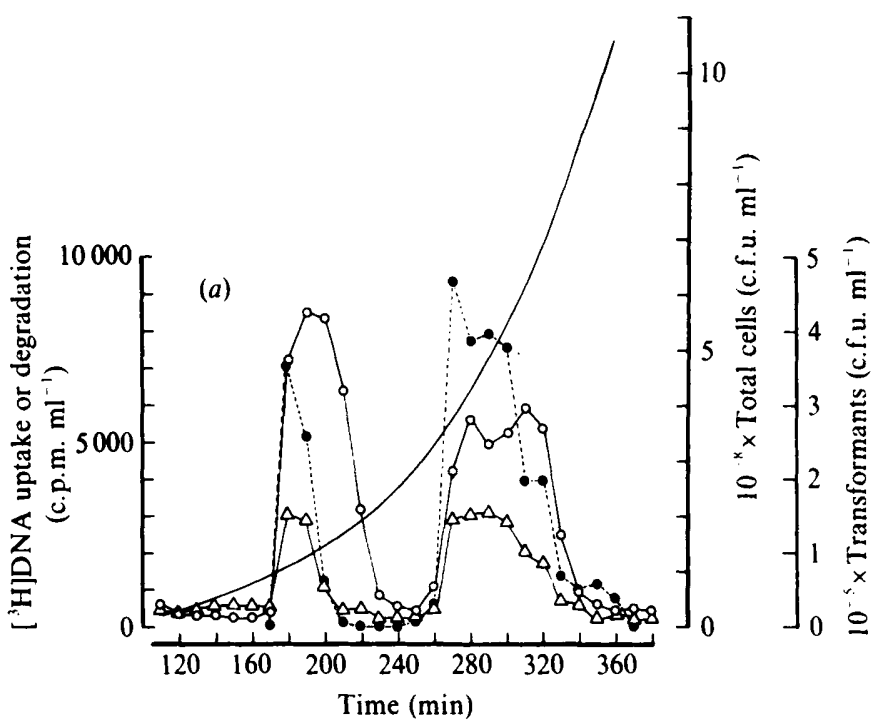

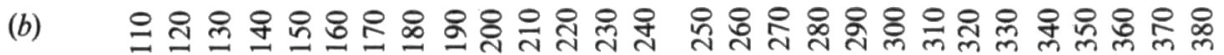
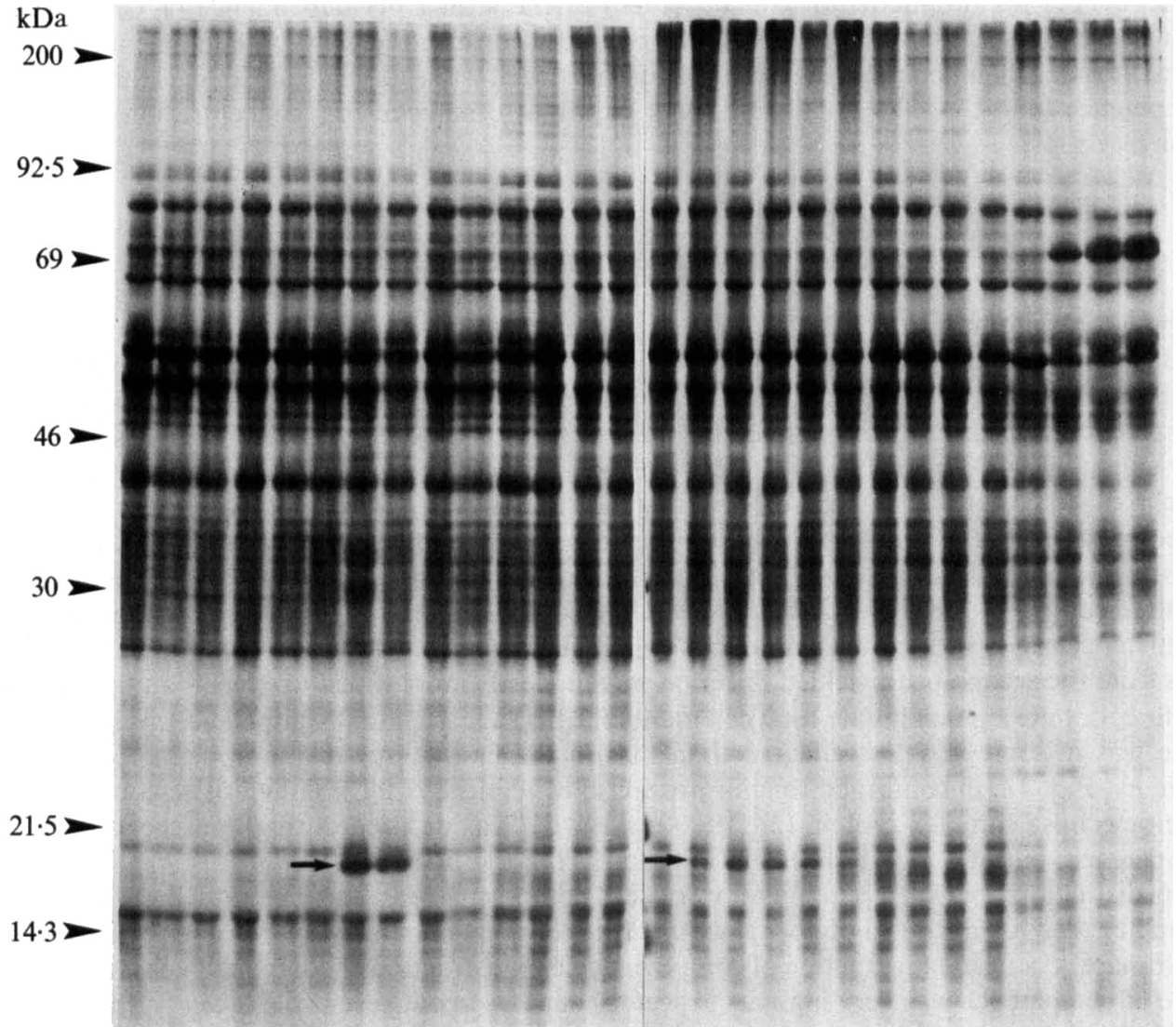

Fig. 4 (continued on next page) 
(c)
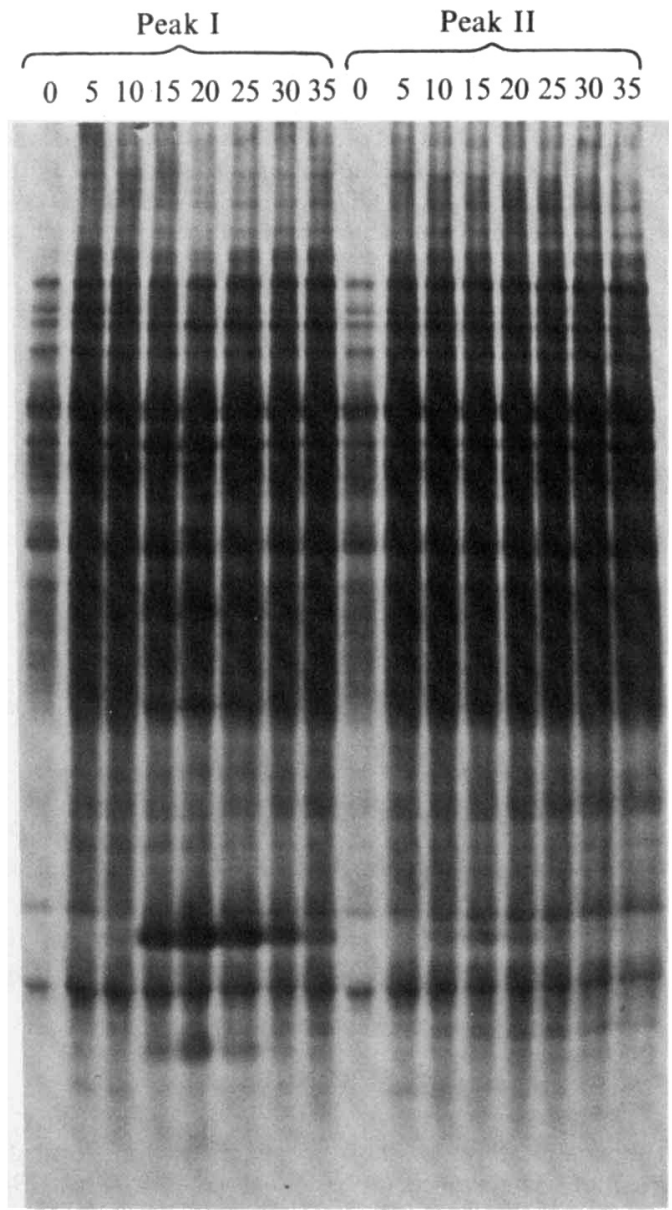

Fig. 4. Comparison of two successive competence cycles. A culture was initiated at $\mathrm{pH} 7.8$ as described for Fig. 1. Sets of samples were harvested at $10 \mathrm{~min}$ intervals. (a) A sample taken at each assay time was thawed and tested for competence and DNA-processing activity during a $10 \mathrm{~min}$ exposure to DNA at $37^{\circ} \mathrm{C}$. - Total cell number $\mathrm{ml}^{-1}$; , novobiocin-resistant transformants; $\mathrm{O}$, DNA degradation; $\triangle$, DNA uptake. (b) Protein synthesis was examined by labelling cells from a parallel set of frozen samples resuspended in $\mathrm{LM}$, by incubating for $10 \mathrm{~min}$ with $\left[{ }^{35} \mathrm{~S}\right]$ methionine. The fluorograph obtained after SDS-PAGE is shown. The time ( $\mathrm{min}$ ) during culture growth at which samples were harvested is indicated. (c) A third sample from the first peak (at $160 \mathrm{~min}$ ), and second peak (at $240 \mathrm{~min}$ ) was examined in more detail by pulse-labelling in successive $5 \mathrm{~min}$ periods, beginning at the indicated times (min) during incubation in LM.

\section{Concluding remarks}

We have extended earlier observations by showing that control of competence is susceptible to two kinds of modulation involving culture $\mathrm{pH}$. First, modest alterations in the initial $\mathrm{pH}$ of the culture medium, in the range 6.8-8.0, strongly affect the specific cell density at which competence first appears during subsequent growth. Second, in media adjusted to a $\mathrm{pH}$ supporting two successive waves of competence, the fraction of cells competent is much lower in the second wave of competence than in the first. The existence of qualitatively different competence cycles succeeding one another in a single culture has not previously been reported. The results suggest that it is possible for a competent pneumococcal population to be a mixture of two cell types, competent and non-competent, much like the situation for $B$. subtilis (Dooley et al., 1971). However, the data here are not precise enough to show whether the competent cells in 


\section{Table 1. Comparison of the fraction of cells competent in competent populations}

Congression analysis was done for the first competent sample for each method, after exposure to $0.1 \mu \mathrm{g} \mathrm{DNA} \mathrm{ml} \mathrm{m}^{-1}$ for $10 \mathrm{~min}$. Competence was determined by measurement of DNA-degrading activity, as described in Methods. The initial $\mathrm{pH}$ of CTM was adjusted to the indicated values. Culture $\mathrm{OD}_{550}$ at each competence cycle is indicated. Diluted samples were plated after DNAase treatment, 120 min outgrowth at $37^{\circ} \mathrm{C}$, and adjustment to $\mathrm{OD}_{550} 0 \cdot 10$. About $200-400$ colonies were counted for each point in duplicate plates; the $95 \%$ confidence limit estimated for each individual frequency is $10 \%$, and for $f_{c}, 20 \%$.

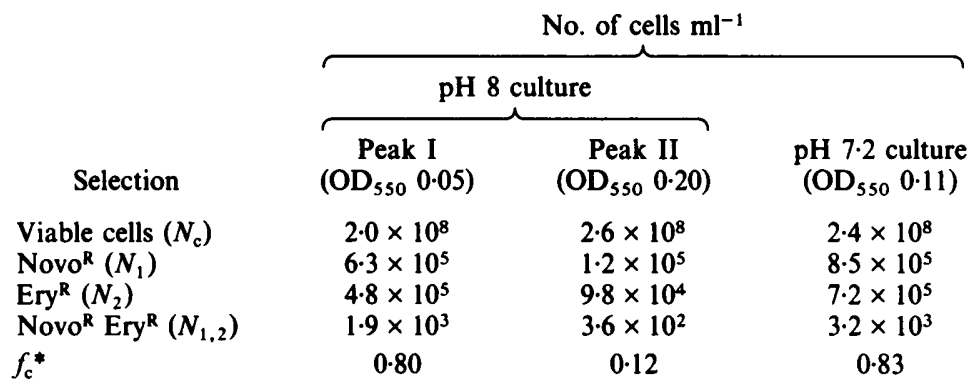

$* f_{c}$, fraction of cells competent, calculated from $f_{c}=N_{1} N_{2} / N_{1,2} \times N_{c}$, to account for segregation of transformable sites during outgrowth (Porter \& Guild, 1969).

such a mixed population are identical to those in a culture at full competence. This finding has an important practical implication; for biochemical studies of competent cells, the 'first cycle' of competence can be expected to provide the better starting material.

This work was supported in part by NIH research grants AI 16783 and AI 19875.

\section{REFERENCES}

Avery, O. T., Macleod, C. M. \& McCarty, M. (1944). Studies on the chemical nature of the substance inducing transformation of pneumococcal types. Induction of transformation by a desoxyribonucleic acid fraction isolated from pneumococcus type III. Journal of Experimental Medicine 79, 137157.

Biswas, G. D., Sox, T., Blackman, E. \& Sparling, P. F. (1977). Factors affecting genetic transformation of Neisseria gonorrhoeae. Journal of Bacteriology 129, 983-992.

BotT, K. F. \& WiLson, G. A. (1967). Development of competence in the Bacillus subtilis transformation system. Journal of Bacteriology 94, 562-570.

CATO, A., JR \& GUILD, W. R. (1968). Transformation and DNA size. I. Activity of fragments of defined size and a fit to a random double crossover model. Journal of Molecular Biology 37, 157-180.

Dooley, D. C., Hadden, C. T. \& Nester, E. W. (1971). Macromolecular synthesis in Bacillus subtilis during development of the competent state. Journal of Bacteriology 108, 668-679.

Fox, M. S. \& Allen, M. K. (1964). On the mechanism of deoxyribonucleate integration in pneumococcal transformation. Proceedings of the National Academy of Sciences of the United States of America 52, 412419.

GRIST, R. W. \& BUTLER, L. O. (1981). The use of M1 medium in transformation of Streptococcus pneumoniae. Journal of General Microbiology 127, $147-$ 154.
Gurney, T., JR \& Fox, M. S. (1968). Physical and genetic hybrids formed in bacterial transformation. Journal of Molecular Biology 32, 83-100.

Herriott, R. M., Meyer, E. M. \& Vogt, M. (1970). Defined nongrowth media for stage II development of competence in Haemophilus influenzae. Journal of Bacteriology 101, 517-524.

Hotchiss, R. D. (1954). Cyclical behavior in pneumococcal growth and transformability occasioned by environmental changes. Proceedings of the National Academy of Sciences of the United States of America 40, 49-55.

JAVOR, G. T. \& ToMASz, A. (1968). An autoradiographic study of genetic transformation. Proceedings of the National Academy of Sciences of the United States of America 60, 1216-1222.

LAEMMLI, U. K. (1970). Cleavage of structural proteins during the assembly of the head of bacteriophage T4. Nature, London 227, 680-685.

LASKEY, R. A. \& Mills, A. D. (1975). Quantitative film detection of ${ }^{3} \mathrm{H}$ and ${ }^{14} \mathrm{C}$ in polyacrylamide gels by fluorography. European Journal of Biochemistry 56, 335-341.

Leidy, G., JAFFeE, I. \& AleXaNdER, H. E. (1962). Emergence of competence (for transformation) of three Haemophilus species in a chemically defined environment. Proceedings of the Society for Experimental Biology and Medicine 111, 725-731.

MCCARTY, M. (1980). Reminiscences of the early days of transformation. Annual Review of Genetics 14, 115 . 
MoRRISON, D. A. (1977). Transformation in pneumococcus: existence and properties of a complex involving donor deoxyribonucleate single strands in eclipse. Journal of Bacteriology 132, 576-583.

MORRISON, D. A. (1978). Transformation in pneumococcus: protein content of eclipse complex. Journal of Bacteriology 136, 548-557.

MorRISON, D. A. (1981). Competence-specific protein synthesis in Streptococcus pneumoniae. In Transformation - 1980, pp. 39-54. Edited by M. Polsinelli \& G. Mazza. Oxford: Cotswold Press.

Morrison, D. A. \& BAKER, M. (1979). Competence for genetic transformation in pneumococcus depends on the synthesis of a small set of proteins. Nature, London 282, 215-217.

Morrison, D. A., Mannarelli, B. \& Vijayakumar, M. N. (1982). Competence for transformation in Streptococcus pneumoniae: an inducible high-capacity system for genetic exchange. In Microbiology 1982, pp. 136-138. Edited by D. Schlessinger. Washington, DC: American Society for Microbiology.

MorRison, D. A., LACKS, S. A., Guild, W. R. \& HAGEMAN, J. M. (1983). Isolation and characterization of three new classes of transformation deficient mutants of Streptococcus pneumoniae that are defective in DNA transport and genetic recombination. Journal of Bacteriology 156, 81-290.

Morrison, D. A., Trombe, M. C., Hayden, M. K., WASZAK, G. A. \& CHEN, J. D. (1984). Isolation of transformation-deficient Streptococcus pneumoniae mutants defective in control of competence, using insertion-duplication mutagenesis with the erythromycin resistance determinant of pAM $\beta 1$. Journal of Bacteriology 159, 870-876.

Nester, E. W. (1964). Penicillin resistance of competent cells in deoxyribonucleic acid transformation of Bacillus subtilis. Journal of Bacteriology 87, 867875.

OtTOLENGHI, E. \& Hotchisiss, R. D. (1962). Release of genetic transforming agent from pneumococcal cultures during growth and disintegration. Journal of Experimental Medicine 116, 491-519.

Pakula, R. \& Walczak, W. (1963). On the nature of competence of transformable streptococci. Journal of General Microbiology 31, 125-133.
Peterson, J. M. \& Guild, W. R. (1968). Fractionated strands of bacterial deoxyribonucleic acid. III. Transformation efficiencies and rates of phenotypic expression. Journal of Bacteriology 96, 1991-1996.

PORTER, R. D. \& GuILD, W. R. (1969). Number of transformable units per cell in Diplococcus pneumoniae. Journal of Bacteriology 97, 1033-1035.

RAINA, J. L. \& RAvin, A. W. (1980). Switches in macromolecular synthesis during induction of competence for transformation of Streptococcus sanguis. Proceedings of the National Academy of Sciences of the United States of America 77, 6062-6066.

SPARLING, P. F. (1966). Genetic transformation of Neisseria gonorrhoeae to streptomycin resistance. Journal of Bacteriology 92, 1364-1371.

SPENCER, H. \& HERRIOTT, R. M. (1965). Development of competence of Haemophilus influenzae. Journal of Bacteriology 90, 911-920.

Tiraby, G., Claverys, J. P. \& Sicard, A. M. (1973). Integration efficiency in DNA-induced transformation of pneumococcus. I. A method of transformation in solid medium and its use for isolation of transformation-deficient and recombination-modified mutants. Genetics 75, 23-33.

Tomasz, A. (1966). Model for the mechanism controlling the expression of competent state in Pneumococcus cultures. Journal of Bacteriology 91, 10501061.

Tomasz, A. (1971). Cell physiological aspects of DNA uptake during genetic transformation in bacteria. In Informative Molecules in Biological Systems, pp. 4-18. Edited by L. Ledoux. Amsterdam: North-Holland.

Tomasz, A. (1973). Cell surface structures and the absorption of DNA molecules during genetic transformation in bacteria. In Bacterial Membranes and Walls, pp. 321-355. Edited by L. Leive. New York: Marcel Dekker.

Tomasz, A. \& Hotchkiss, R. D. (1964). Regulation of the transformability of pneumococcal cultures by macromolecular cell products. Proceedings of the National Academy of Sciences of the United States of America 51, 480-486.

TOMASZ, A. \& Mosser, J. L. (1966). On the nature of the pneumococcal activator substance. Proceedings of the National Academy of Sciences of the United States of America 55, 58-66. 